\title{
State-of-the-Art Review on the Energy Performance of Semi-Transparent Building Integrated Photovoltaic across a Range of Different Climatic and Environmental Conditions
}

\author{
Reza Khalifeeh ${ }^{1}$, Hameed Alrashidi ${ }^{2}$, Nazmi Sellami ${ }^{3} \mathbb{D}$, Tapas Mallick ${ }^{4}\left(\mathbb{D}\right.$ and Walid Issa ${ }^{1, *}$ (D) \\ 1 Department of Engineering \& Mathematics, Sheffield Hallam University, Sheffield S1 1WB, UK; \\ b7022142@my.shu.ac.uk \\ 2 Kuwait Fund for Arab Economic Development, Mubarak Al-Kabeer St., Kuwait City, P.O. Box 2921, \\ Safat 13030, Kuwait; basicolor@hotmail.com \\ 3 School of Engineering, Robert Gordon University, Aberdeen AB10 7JG, UK; n.sellami@rgu.ac.uk \\ 4 Environment and Sustainability Institute, University of Exeter Penryn Campus, Penryn TR10 9FE, UK; \\ T.K.Mallick@exeter.ac.uk \\ * Correspondence: walid.issa@shu.ac.uk
}

Citation: Khalifeeh, R.; Alrashidi, H.; Sellami, N.; Mallick, T.; Issa, W. State-of-the-Art Review on the Energy Performance of

Semi-Transparent Building Integrated Photovoltaic across a Range of Different Climatic and Environmental Conditions. Energies 2021, 14, 3412. https://doi.org/10.3390/en14123412

Academic Editor: Chi-Ming Lai

Received: 12 May 2021

Accepted: 1 June 2021

Published: 9 June 2021

Publisher's Note: MDPI stays neutral with regard to jurisdictional claims in published maps and institutional affiliations.

Copyright: (c) 2021 by the authors. Licensee MDPI, Basel, Switzerland. This article is an open access article distributed under the terms and conditions of the Creative Commons Attribution (CC BY) license (https:// creativecommons.org/licenses/by/ $4.0 /)$.

\begin{abstract}
Semi-transparent Building Integrated Photovoltaics provide a fresh approach to the renewable energy sector, combining the potential of energy generation with aesthetically pleasing, multi-functional building components. Employing a range of technologies, they can be integrated into the envelope of the building in different ways, for instance, as a key element of the roofing or façade in urban areas. Energy performance, measured by their ability to produce electrical power, at the same time as delivering thermal and optical efficiencies, is not only impacted by the system properties, but also by a variety of climatic and environmental factors. The analytical framework laid out in this paper can be employed to critically analyse the most efficient solution for a specific location; however, it is not always possible to mitigate energy losses, using commercially available materials. For this reason, a brief overview of new concept devices is provided, outlining the way in which they mitigate energy losses and providing innovative solutions for a sustainable energy future.
\end{abstract}

Keywords: BIPV; energy performance; semi-transparent solar cells; OPV; power; thermal; optical performance; soiling; shading; retrofitting

\section{Introduction}

In 2015, the United Nations General Assembly adopted a series of Sustainable Development Goals (SDGs), including the requirement to protect the planet's environment [1] SDG 7 specifically highlighted the importance of 'ensuring access to affordable, reliable, sustainable and modern energy for all [2]'. According to [3], sustainable energy is derived from the natural flows of energy originating with bioenergy, direct solar energy, geothermal energy, wind and ocean energy (tide and wave). Photovoltaic systems, which can be seamlessly integrated in the built environment, are particularly significant in meeting the rising demands for energy resulting from the accelerating rate of urbanization, in a sustainable way. It is worth mentioning that the solar systems can be divided in photovoltaic (PV) and solar thermal (ST) systems. Building Integrated Photovoltaics (BIPV) and Building Integrated Solar Thermal (BIST) are PV or ST panels integrated into the building envelope, combining the energy generation with other functions [4]. Several research projects have been discussed in [4], in particular, for integration of solar energy systems in heritage sites and buildings, in addition to proposing a framework for reviewing these projects.

The energy performance of semi-transparent Building Integrated Photovoltaics (BIPV), in a variety of climatic and environmental conditions, is the subject of interest in this review. 


\subsection{Advantages of BIPV}

Semi-transparent Building Integrated Photovoltaics (BIPV) offer a fresh approach to generating renewable energy, potentially delivering 'costs competitive with fossil fuels [5]'. In this case, PV modules are integrated into the design of the building, offering a multifunctional solution, which combines the function that the building construction element would normally perform, as well as generating solar power. In addition, semi-transparent BIPV also offer the possibility of conserving energy, reducing the amount consumed to achieve 'thermal comfort', in addition to offering aesthetically pleasing lighting effects [6]. Integration of the PV-system has several advantages, including the ability to maximise the power generation capacity, through utilising more of the surface area of the building in urban environments, where there are many skyscrapers [7]. BIPV modules can potentially be installed into any part of the building envelope, providing opportunities for solar electric architects to design energy efficient, aesthetically pleasing buildings [8].

\subsection{Framework for Analysing Energy Performance}

The basic BIPV technology and applications have been extensively studied in the literature [9]. In recent years, research efforts focus on novel designs to increase the efficiency both at the system level and also at the PV cell level. All are supported and validated by simulation and experimental work. Another important point that affects the power output is the grid integration of renewable energy sources when the BIPV system is considered as a whole. The purpose of this approach is to minimize the loss of electricity on electronic components, transformers, and long distribution lines by altering the configurations of the distribution systems.

There are a wide range of semi-transparent BIPV systems, which can be classified according to the technology employed, the application-type and the way in which the system is configured [9-11]. There is a strong correlation between this classification and the energy performance of the BIPV-system. Solar electric architects need to take this into account in the design process Figure 1 presents a methodology framework, aimed at facilitating understanding of the most energy efficient solution for each location [12]. It details the key factors impacting energy production and conservation, ensuring that all are taken into consideration, in creating the most efficient solution.

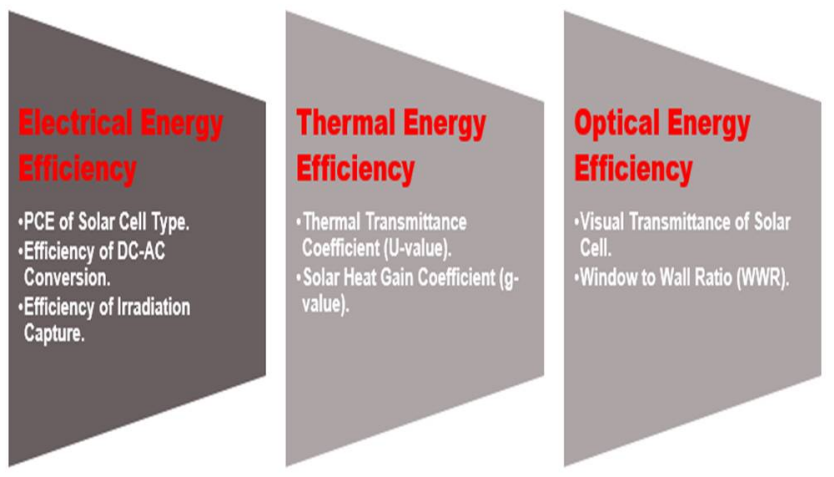

Figure 1. Framework for analysing the energy performance of semi-transparent BIPV.

\section{Power Performance}

The first aspect of this framework concerns the way in which the electrical output or power performance of the BIPV system may be critically evaluated.

\subsection{PCE of Different Technologies}

The power conversion efficiency (PCE) is defined as the ability of a solar cell to convert light to electricity, and it can be calculated using the equations in [13]. PCE of the specific technology employed in the BIPV system is assumed to be the most accurate predictor of its potential for generating electrical power. According to [14], energy conversion efficiency 
is 'the useful energy output divided by the energy input', which in the case of solar cells is the percentage of the sun's energy the PV cell is capable of converting to electrical power. In [15], collated information outlining the 'conversion efficiency' of a wide variety of different PV technologies, i.e., Silicon-based crystalline, thin-film and 'new concept devices'. These are described below, with specific information about the PCE for each set out in Figure 2.

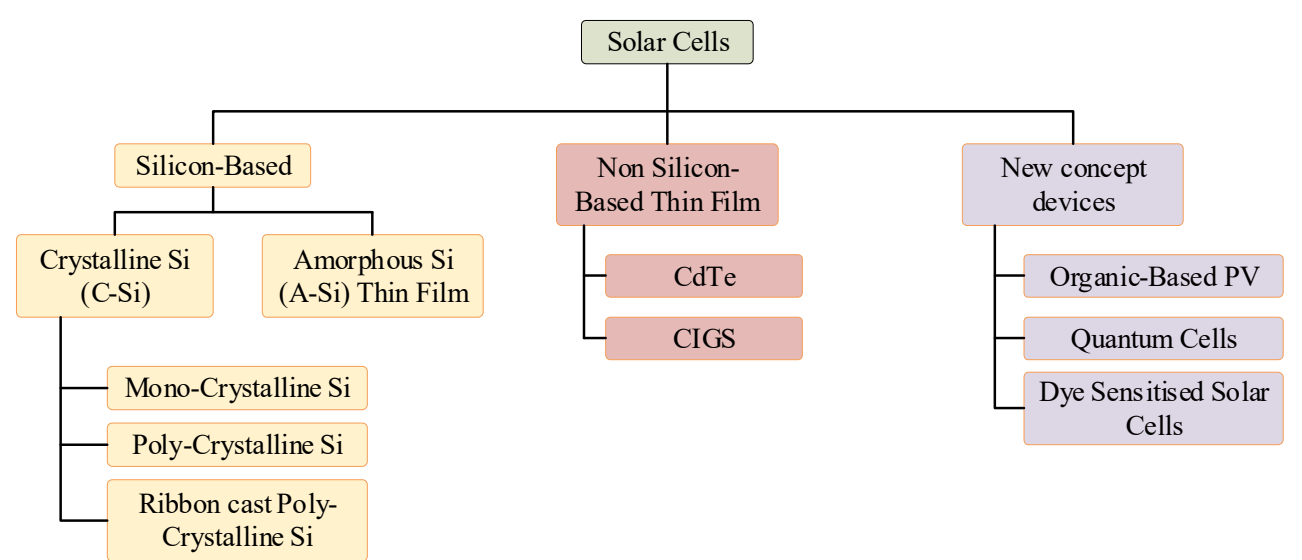

Figure 2. PV Technologies [11].

\subsubsection{Silicon-Based Crystalline Solar Cells}

There are two types of Silicon-based crystalline solar cells-monocrystalline and polycrystalline. Currently, the highest efficiencies are achieved by using monocrystalline silicon, which has a higher PCE value than the poly-crystalline cells [10]. Semi-transparency of the normally opaque, silicon-based PV cells can be achieved by changing the amount of space between modules to allow the transmittance of light, but this does have an impact on overall efficiency. Their efficiency is also sensitive to environmental factors.

\subsubsection{Thin-Film Solar Cells}

Silicon-based thin-film cells comprise a very thin layer of amorphous silicon (a-Si), which is vacuum-deposited along with 'transparent conductive oxides', creating 'a semiconductor on a glass substrate'. Although the modules are tinted, ' $20 \%$ light transmission' is achieved due to the 'ultra-thin' nature of the product [16]. Non-silicon-based thin-film cells use semiconductors such as Gallium Arsenide (GaAs), Cadmium Telluride (CdTe), Copper Indium Diselenide ( $\mathrm{CInSe}_{2}$ ) and Copper Indium Gallium Selenide (CIGS). In this case, the solar cells are manufactured by vapour-deposition on conductive glass, with the solar cells being subdivided into 'thin linear cells, broken up by metallic or transparent lines [11]. Laser ablation can be used to achieve semi-transparency, by removing layers to allow light through. While non-silicon PV modules are generally more economic to produce, achieving semi-transparency results in a product with lower energy efficiency and a limited degree of transparency [17].

\subsubsection{Coloured BIPV Technologies}

The turning point in the acceptance of BIPV applications has been the development of hidden coloured BIPV modules. This module typology, which includes several different technologies, can hide the PV cells behind coloured patterns which hinder the perception of the original material of the cells [18]. In this way, the modules appear very similar to standard construction materials. This solution appears appropriate also for architecturally sensitive areas, i.e., historical centres, vernacular and historic buildings and natural and cultural landscapes, thanks to the aesthetical and technological advances related to low-rate reflection, mimetic appearance, compact shape and geometric flexibility, enabling a flexible integration of large sets of unexploited vertical and horizontal envelope surfaces $[19,20]$. 
However, multilevel integration aspects should be considered like technical, aesthetic and energy aspects [18].

\subsubsection{New Concept Devices}

Emerging technologies, known as 'new concept devices', could be instrumental in transforming the sector. These cells often still employ 'thin-film' technology, but the cost is reduced by using new materials such as 'solar inks, nanotubes, organic dyes, conductive plastics, etc. [6]'. Developers are seeking to create products, which are lower cost but still offer high levels of efficiency and are effective at addressing current limitations.

\subsection{Efficiency of DC-AC Conversion Process}

The efficiency of a solar array is also impacted by the compatibility of the different components, which make up the system. This includes the Power Conditioning System (PCS) which refers to devices that use power electronics technologies to convert electric power from one form to another as DC-DC and DC-AC converters [21]. PCS requires the input power to be around $30-50 \%$ of the rated power of the PCS to achieve anticipated rates of $94.5 \%$ in the DC-AC conversion process. Incompatibility may result in a reduction of around $8 \%$ in electrical energy performance [22]. Losses can be avoided by ensuring that system design supports maximum efficiency.

\subsection{Efficiency of Irradiation Capture}

Irradiation capture is the ability to capture the optical energy which is impacted by both environmental factors and by the design of the electrical system and has a significant impact on energy efficiency. Calculation equations can be found in [23]. Basically, the PCS has a minimum voltage at which it operates, meaning that a minimum intensity of irradiation is required for the system to automatically turn on. Where the solar radiation intensity is below this level, the system remains inactive, failing to generate any solar energy. This irradiation capture inefficiency may undermine the power performance of the solar array in a variety of meteorological and installation conditions. Authors in [22] discovered that, depending on the orientation of the system, somewhere between $4.6 \%$ and $15.7 \%$ of the annual irradiation may not be used for power generation, due to low levels of irradiation failing to trigger the standby function on the PCS. Figure 3 shows different oriented solar cells systems. Four different arrays were installed on horizontal $\left(\mathrm{HR} 0^{\circ}\right)$, south-inclined (SI $\left.30^{\circ}\right)$, south vertical $\left(\mathrm{SV} 90^{\circ}\right)$, and west vertical $\left(\mathrm{WV} 90^{\circ}\right.$ ) directions, respectively on a building in Daejeon in Korea. PEC is used by the authors as a figure for power conditioning system (PCS) conversion efficiency-corrected performance which take into account the PCS stand-by power, converters efficiencies, module temperature and dust and soiling. Each array consisted of 12 transparent-Si BIPV modules connected in 6 series $\times 2$ parallel and had an installed capacity of $0.528 \mathrm{kWp}$. The evaluation of evaluate the system loss and capture loss is conducted based on the monitored data. The $8.3 \%$ loss is caused by the PCS conversion losses.

The combined effect of losses associated with the impact of the Power Conditioning System standby-mode on irradiation capture and DC-AC conversion inefficiencies could be significant [24]. Lee et al. [22] demonstrated that an overall performance ratio of no greater than $75 \%$ could be anticipated (Figure 3), with capture losses of around $17 \%$ and system losses of around $8 \%$, not being out of the question. Optimising the system design to ensure efficiency in the DC-AC conversion process and thereby maximising irradiation capture is likely to have a significant impact on the electrical power performance of the system. 


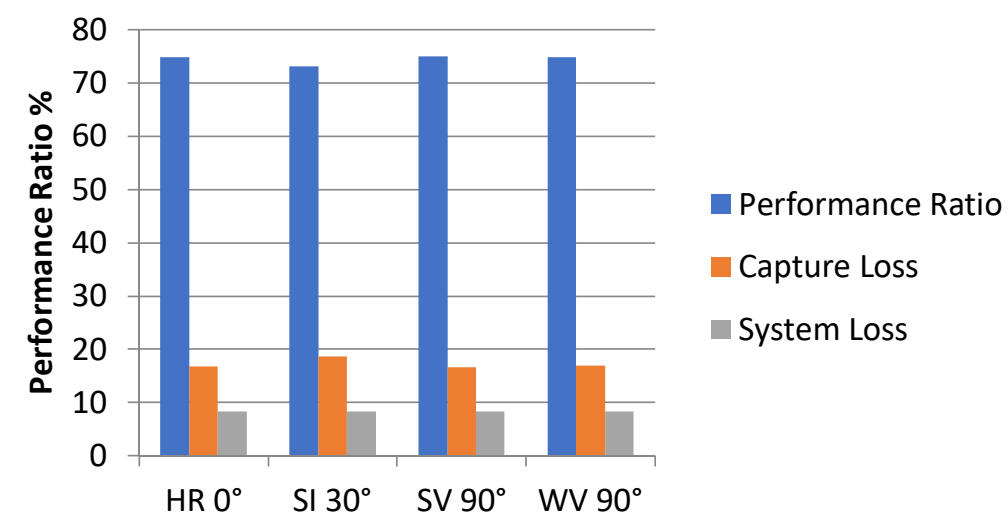

Figure 3. PCS Performance ratio of four different Solar Arrays [22].

\section{Thermal Performance}

In addition to generating electrical power, semi-transparent BIPV are also useful in contributing to thermal comfort and reducing the energy demands for regulating the internal temperature of the building [25]. Similar to electrical power performance, the thermal performance of a semi-transparent BIPV system is not only impacted by external factors but also by the inherent features of the semi-transparent BIPV module employed. According to [26], thermal energy performance is related to both the 'thermophysical properties of the materials' and the 'transmission and absorption coefficients' of the transparent material, in other words, the thermal efficiency of the glazing components, the degree of transparency of the solar cell-type and, potentially, the manner in which transparency is achieved.

As noted previously, the semi-transparency of 'crystalline silicon PV arrays is created by the transparent glazing surrounding the opaque solar cells, whereas thin-film technologies achieve semi-transparency by using laser ablation to remove layers of the substrate. For this reason, assessing the thermal performance of semi-transparent BIPV is a relatively complex matter, with standard methods designed for conventional glazing potentially producing erroneous results $[27,28]$. Both the U-value, which measures heat transmission through the BIPV-module and can be calculated using the equations in [29], and the 'solar heat gain coefficient' (SHGC), also known as the g-value, which measures the amount of heat transmitted into the building due to solar radiation, need to be taken into account [26]. SHGC can be calculated using the equations in [30].

It would, therefore, seem important to examine both the impact of the solar cell-type and the type of glazing on the thermal performance of the PV module. Most of the research on the thermal performance of semi-transparent BIPV has involved solar cells employing thin film technologies, such as amorphous silicon (a-Si) and cadmium telluride (CdTe).

\subsection{Solar Heat Gain (g-Value)}

The solar heat gain coefficient (g-value) has been linked to the thickness of the semiconductor film in the photovoltaic cell. Chae et al. [31] carried out an evaluation of thin film semi-transparent a-Si solar cells, which employed different thickness of amorphous silicon. They found that while the thermal transmittance (U-value) was similar, cells with a lower g-value (SHGC), demonstrated strong correlation between the thickness of a-Si layers and energy conservation in lower latitudes. In another study, Martin-Chivelet et al. [27] concluded that the degree of transparency of PV modules had 'no appreciable influence' on thermal transmittance (U-value), whereas differences associated with SHGC (g-value) were noted.

\subsection{Thermal Transmittance (U-Value)}

Another study, carried out by Al Rashidi et al. [29], examined the performance of thinfilm CdTe cells, compared to a conventional single-glazed window. They found that the U-value of the BIPV window was half of that of the single glazed unit and that the SHGC 
(g-value) was over 70\% lower, meaning that the thermal performance of the CdTe was much better than that of the regular glazing. Different glazing structures, for a crystalline silicon (c-Si) BIPV cell, were also investigated by Ghosh et al. [32]. They found that the BIPV vacuum system was most effective in delivering 'thermal comfort', with values up to $39 \%$ above the BIPV double-glazed system. In all these cases, the results obtained were locationdependent, with different results being obtained under different climatic conditions and at different latitudes, underlining the need for bespoke location-specific solutions.

Figure 4 shows the overall heat transfer coefficient (U-value) of a CdTe BIPV window and a single glazed window when they are tested indoor under sun simulator showing the different temperature figures, while the outdoor test is shown in Figure 5. It is worth mentioning here that the sample transparency was 25\% and was tested in Penryn, UK in indoor and outdoor setups. The indoor simulator was set at $1000 \mathrm{~W} / \mathrm{m}^{2}$ constant solar exposure for eight hours. The maximum solar heat gain for the CdTe BIPV window was found as $20 \%$ which was $73 \%$ lower than a $72.8 \%$ transparent single glazing. CdTe BIPV had an average U-value of $2.7 \mathrm{~W} / \mathrm{m}^{2} \mathrm{~K}$ in the indoor and outdoor experiments. This average is lower than that of the single glazing that showed $5.7 \mathrm{~W} / \mathrm{m}^{2} \mathrm{~K}$ in the indoor experiment and $5.6 \mathrm{~W} / \mathrm{m}^{2} \mathrm{~K}$ in the outdoor experiment.
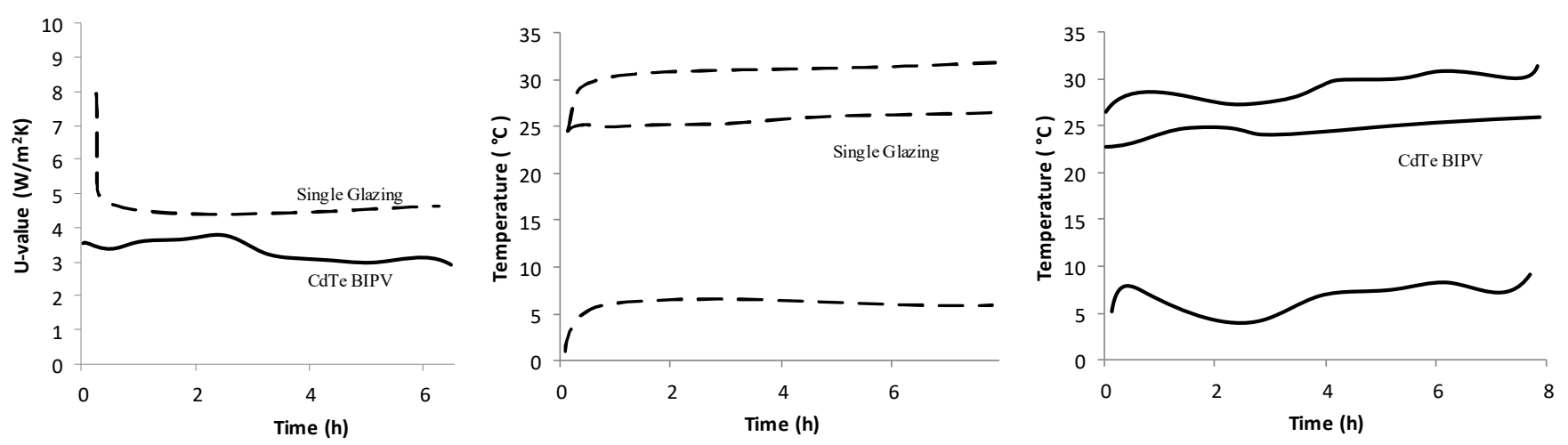

Figure 4. Overall heat transfer coefficient (U-value) of a CdTe BIPV window and a single glazed window-Indoor test [29].

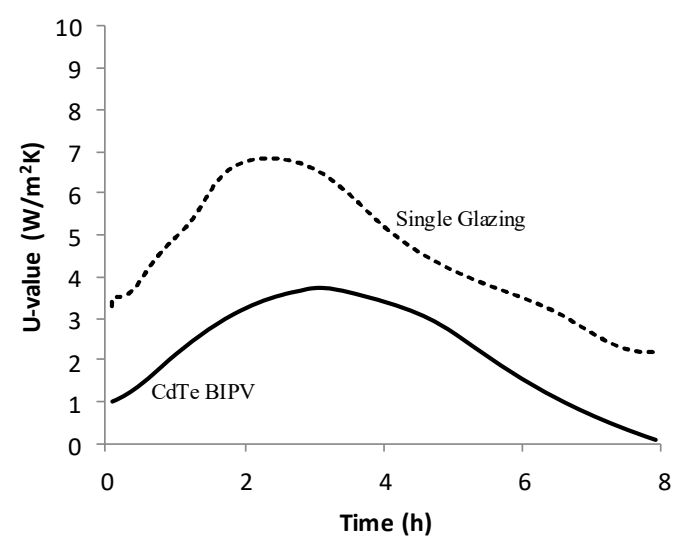

Figure 5. Diurnal variation of thermal transmittance (U-value) of a CdTe BIPV window and a single glazed window-Outdoor test [29].

\section{Optical Performance}

Semi-transparent BIPV also improve the visual comfort of a building by reducing unwanted solar glare. In contrast to the way thermal energy performance is calculated, optical performance is exclusively linked to the degree of transparency of the semi-transparent $\mathrm{BIPV}$ module. For this reason, optimising lighting-energy conservation is related to the relationship between the average visible transmittance (AVT) and the window to wall ratio (WWR). AVT is an optical property that indicates the fraction of visible light transmitted through the window while WWR is the ratio between the glazed surface and the gross 
façade area [33], higher outputs being achieved where more transparent BIPV are used over a larger WWR.

Even so, the way in which transparency is achieved has a huge bearing on the outcome. Thin-film technologies, which have not been customised, currently offer visible transmittances of around 5\%, on the 'orange-brown spectrum', which fail to meet the required 'daylighting performance', resulting in 'severe visual discomfort [34]. Where laser ablation has been used to increase transparency, higher levels of visible transmittance can be achieved, allowing optical performance to be optimised. This, however, results in lower levels of power generation for the area of glazing. Using silicon laminates provides a third option, offering higher rates of PCE, but creating transparency by using a 'patterned array of opaque solar cells' diminishes the overall visual effect [34]. While standard semitransparent BIPV-technology has its limitations, there are emerging technologies, which show promise.

Despite these limitations, there has been a considerable amount of research carried out to investigate the optical performance of standard semi-transparent BIPV windows in terms of Continuous Daylight Autonomy (cDA) [35] and the spatial Daylight Autonomy (sDA) [36]. A simulation carried out by [37] examined the daylight performance of perimeter office façades utilizing semi-transparent photovoltaic-windows. They investigated three façade configurations, incorporating Si-based opaque spaced cells and thin film technologies, in a way that ensured sufficient daylight 'within the perimeter zone' throughout the year. The three-façade system comprised an opaque lower section, extending $0.8 \mathrm{~m}$ upwards to correspond with 'work-plane height'; a middle section which maximises external viewing (to $2.0 \mathrm{~m}$ above the floor) and a third section, designed to allow sunlight to enter the room, while minimising glare. Windows with five 'effective visible transmittance' values (Figure 6), ranging from 10-50\%, were chosen, one set having an outer glass layer only, the other being an insulated double-glazed unit (IGU). Visible effective transmittances (VET) ranged from $6-50 \%$. Three different configurations were studied: one utilising only PV-film, another utilising only Si-based technology and the last combining both. The optimum configuration according to the simulation was achieved using a 30\% VET Semi-transparent PV (STPV) module 'integrated as the outer glass layer of a double glazed low-e window. VET higher than $30 \%$ would have resulted in poor power output and unacceptably high solar gains. This study would seem to suggest that standard technologies can be combined in a way that optimises their power, thermal and optical performance.

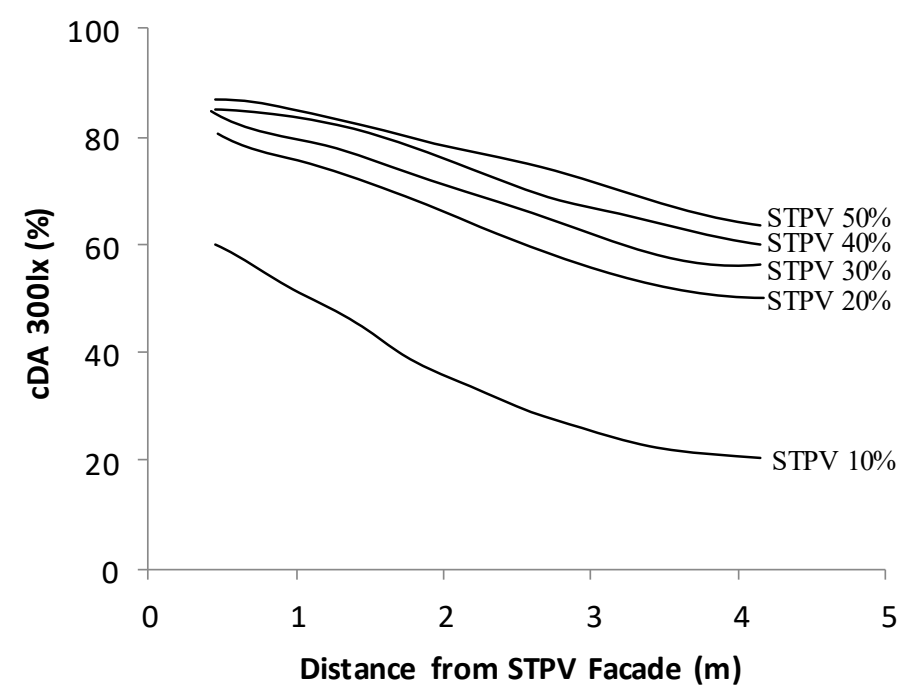

Figure 6. Spatial Daylight Autonomy for a BIPV façade with various visible effective transmittances $(10 \%$ to $50 \%)$ [37]. 
Another interesting study combined the use of semi-transparent BIPV windows and daylight dimming systems [38]. Researchers assumed that using less electricity for lighting could reduce the cooling load, resulting in a daylight-dimming system being incorporated along with three different types of BIPV solar cells, ranging in transparency from $10-40 \%$. A light sensitive cell controlled the electric lighting system, maintaining it at 323 lux in rooms orientated towards the four points of the compass. The research demonstrated lighting energy savings ranging from $3-14 \%$, with the highest levels associated with increased window-transparency. The greatest impact was achieved with the east-facing window, although the system design did not compensate for excessive direct sunlight entering early in the day. In addition to the reduction in energy-consumption associated with the lighting system, 'peak cooling demands' were reduced by up to $26 \%$, resulting in overall energy savings in the range of $12-20 \%$, emphasising the close link between optical and thermal energy performance.

\section{Climatic and Environmental Effects}

This framework can be employed to investigate the potential energy efficiency in a specific location, by understanding the way in which electrical, thermal and optical performance is affected by different climatic and environmental conditions.

\subsection{Climatic Effect on PCE}

The electrical energy performance of a semi-transparent BIPV system is affected by the installation environment, with climatic, geographical and environmental effects being observed. According to [39], the PCE-value of the solar cell decreases with elevated operating temperature, compromising the efficiency of the system. Indeed, Popovici et al. in [40] documented a reduction of around $0.45 \%$ for every degree of increase in temperature over the optimum value of $25^{\circ} \mathrm{C}$. The reduction in PCE is described by the following Equation (1), where $\eta$ is the cell/electrical efficiency value; $\beta$ is the temperature coefficient, and $T$ is temperature [41]. The subscript $c$ denotes a cell, ref denotes reference value at reference conditions, and $T$ denotes a referenced tilted plane.

$$
\eta_{c}=\eta_{\text {Tref }}\left[1-\beta_{r e f}\left(T_{c}-T_{r e f}\right)\right]
$$

Even in temperate zones, where climatic conditions are closer to ideal, the solar cell itself generates heat as a result of electrical resistance of the solar cells, which amounts to the difference between the solar energy absorbed and the electrical energy produced [42].

Researchers have found that the temperature of PV modules changes slowly, however, with a 'time lag' between the incidence of 'solar radiation' and the rise in PV module temperature. This varies with the solar cell type and the type of glazing used. Yoon et al. [43] stated that surface temperature not only affects PCE but also may impact 'indoor cooling and heating energy consumption', as well. Crystalline silicon cells are rather more prone to reductions in efficiency than non-crystalline solar cells, with relative reductions in efficiency of $0.45 \%$ and $0.2 \%$, per $1{ }^{\circ} \mathrm{C}$ rise in temperature.

\subsection{Environmental Effect on Irradiation Capture}

The ambient temperature of the environment and solar irradiation are not the only climatic factors which affect energy efficiency. The position of the sun and amount of direct solar radiation are significant, as are the effects of soiling and shading.

\subsubsection{Effect of Angle of Orientation and Inclination}

The position of the sun and the amount of direct solar energy are defined by the solar altitude angle $(\mathrm{h})$ and the solar azimuth angle (A). The solar altitude $(\mathrm{h})$ is the angle between the horizontal surface of the earth and the direct line to the sun, in contrast to the solar zenith angle $(\theta z)$, which is the angle between the vertical line and the line to the sun. In the Northern Hemisphere, the solar azimuth angle (A) is the angle of the incident 
beam of radiation from the south. These angles define the physical position of the sun, a particular time in the day, and determine the optimum angle of orientation $(\alpha)$ or the tilt $(\beta)$ of the solar installation.

It should be noted, however, that some authors [44] use the term, 'azimuth angle of the BIPV', which rather confusingly actually refers to the angle of orientation $(\alpha)$ in relation to the azimuth, rather than the solar azimuth angle (A). Furthermore, direct solar radiation is only one component of the overall incident solar radiation, with diffuse and reflected radiation also playing a part [45]. In some situations, the impact of these two additional components can be significant.

A study carried out by [44] examined the optimum angle of orientation in relation to the azimuth and inclination of BIPV panels in an urban environment. In general, it was found that the optimum angle of inclination $(\beta)$ for a solar panel was equivalent to the latitude of the location. This was confirmed by a computer simulation, focusing on twenty different locations in the northern hemisphere, with significant discrepancies increasing somewhat non-uniformly with latitude [46].

Further research on optimum tilt angle $(\beta)$ was carried out by [45], who demonstrated differences between fixed and adjusted tilt angle in Jeddah, Saudi Arabia (latitude: $21.5^{\circ} \mathrm{N}$, longitude: $39.17^{\circ} \mathrm{E}$ ). The test has four samples with different tilt angle adjustment and configuration observed on a monthly, seasonally, half-yearly and yearly basis. They compared the effect of adjusting the tilt angle daily, as opposed to keeping the solar module in a fixed position, finding that the electrical output was just over $7 \%$ less when no adjustments were made as shown in Figure 7.

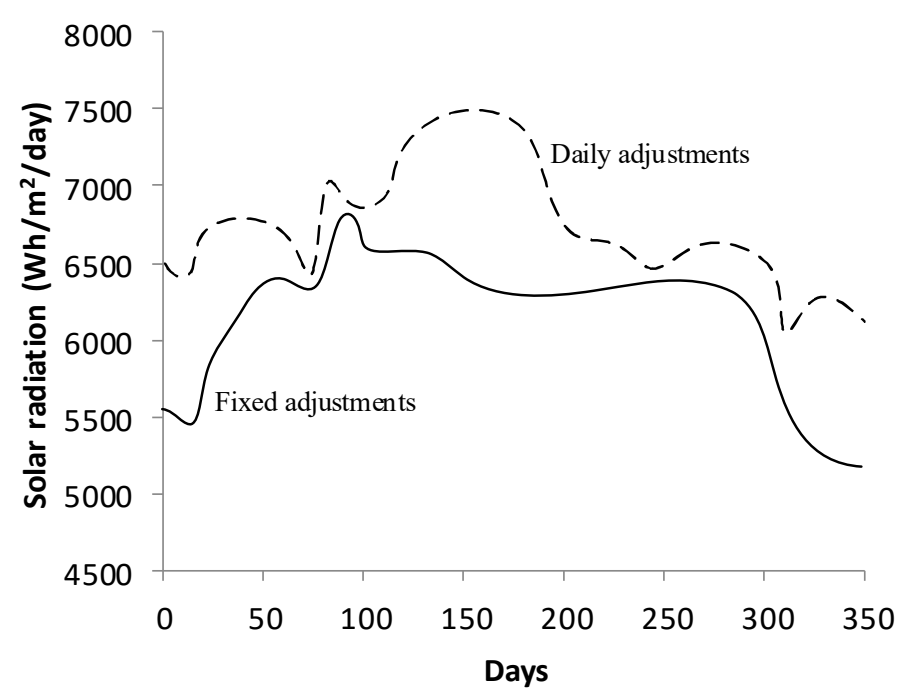

Figure 7. Daily solar radiation on fixed and daily adjusted surfaces [45].

Obviously, for the vast majority of BIPV installations, it is not possible to adjust the angle of orientation or inclination of the panel as the module would generally form a fixed part of the structure. In this situation, it is necessary to determine optimum configuration, within these constraints.

According to [47], the optimal angle of orientation, in relation to the azimuth, was a value of $0^{\circ}$, when the panel is south-facing in the northern hemisphere and north-facing in the southern hemisphere. The variation in energy-saving rates for different solar azimuth angles was examined more closely through research carried out on semi-transparent thinfilm façades installed on an office building in the Tianjin city, China, cold-zone [48]. The highest energy-saving rates of over $60 \%$ were achieved by the south-facing DSF (Doubleskin Façade) as compared to just under 14\% saving with SSF (Single-skin Façade, facing east) as shown in Figure 8. L-T denotes to low transmittance, H-T to high transmittance, SPVF to single photovoltaic façade, DPVF to double photovoltaic façade, DCPVF to double closed photovoltaic façade and DVPVF to double ventilated photovoltaic façade. 


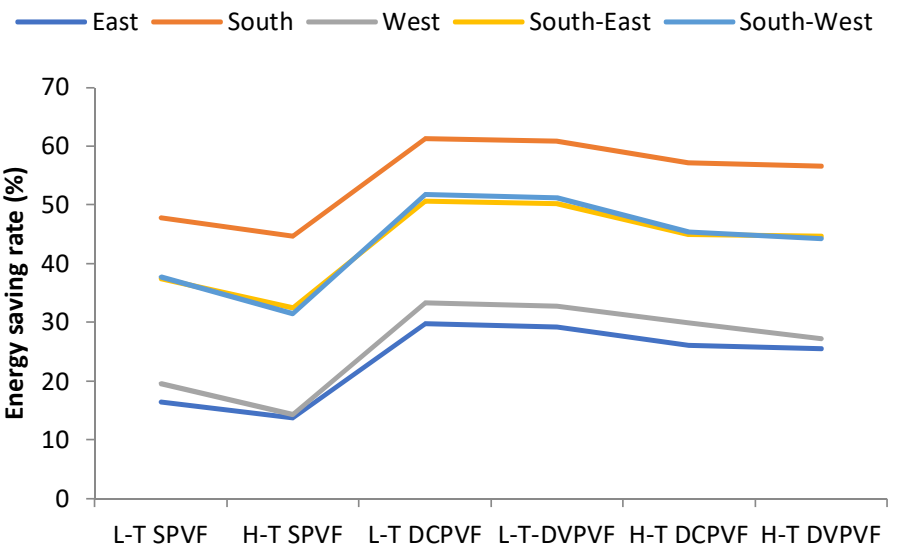

Figure 8. Energy saving rates of Photovoltaic façade (PVF) at different orientations in China coldzone [48].

South-east and south-west facing façades performed similarly, with energy savings of around $50 \%$ for DSF and west facing façades performing around $4 \%$ better than eastfacing, at best. In general, energy-saving rates are therefore found to be much more sensitive to the angle of orientation than any other factor, with the comprehensive heatgain coefficient (CHGC) demonstrating greater sensitivity than visible light transmittance (VLT). Interestingly, VLT is a much more significant factor than CHGC for the poorly performing east-facing façade. Hence, both the angle of inclination and the angle of orientation are very important in determining the energy efficiency of semi-transparent BIPV; however, in urban settings the impact of shading by adjacent buildings may result in assumptions needing to be revised [44].

\subsubsection{Effects of Shading}

While BIPV modules installed on high-rise commercial or residential buildings offer very significant energy-saving potential, this can be dramatically affected by the proximity of nearby buildings. A striking example from the Norwegian city of Trondheim cited a BIPV system retrofitted on a seven-story office building, with BIPV-façades integrated into southand west-facing façades. The system was orientated for optimum energy performance; however, a year after its commission, a newly-erected, twenty-one storey hotel caused the south-facing panels to be partially obscured, impacting the 'solar production and energy performance of the system [49]. Determining the effect of partial shading on BIPV performance is a complicated matter, due to the 'non-uniform and dynamic conditions', which occur over time, impacting both urban planning and the retrofitting of BIPV on existing buildings [50]. Two types of adverse shadow-effects' have been observed, including shading due to the sun being 'trapped behind an adjacent building' and the 'sky blocking effect', which causes 'diffuse irradiation' and 'horizontal brightening', from that 'portion of the sky to become zero [44].

A Python-based tool was used to analyse the amount of solar radiation falling on building surfaces in Tehran, Iran, determining the most optimal surfaces for BIPV installation, taking into account the shading from surrounding buildings. The heat map analysis is shown in Figure 9, which shows different potential of PV installation according to the heat concentration and distribution. 

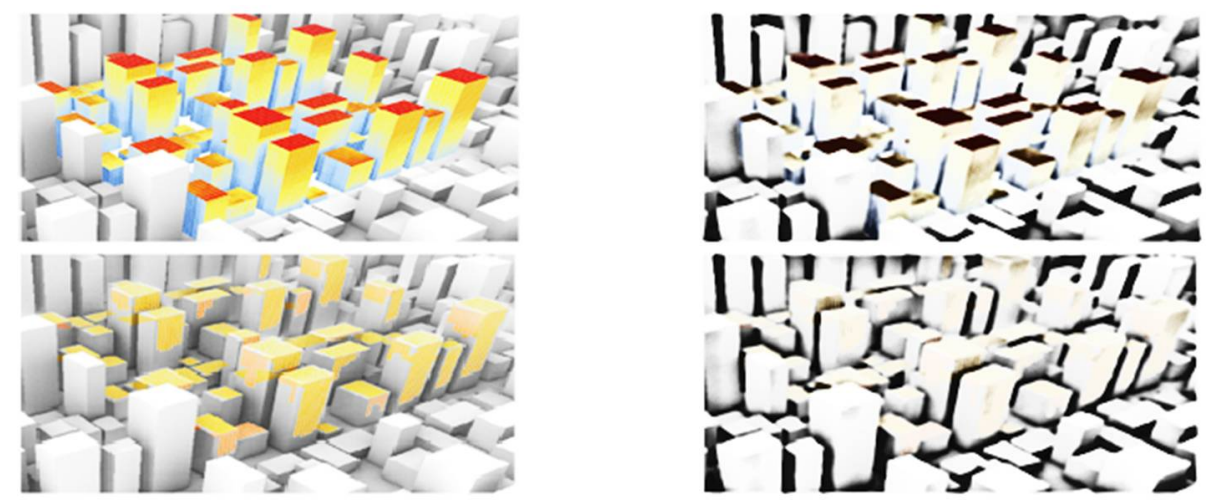

Figure 9. Radiation analysis, meshing and calculation of average annual radiation (upper) defining the installation boundary based on thresholds (lower) [50].

In [46], the BIPV panels are integrated into the roof of a sample building in Delhi, India. The adjacent building is situated in the south direction to investigate the impact of shadow. Figure 10 presents the influence of different positions of the adjacent building on solar irradiation received by south-faced BIPV panel for the duration in September 2017. It can be noticed from Figure 10 that the irradiation values are most adversely influenced by the adjacent building situated in the south direction as for this location the shadow effect is maximum.

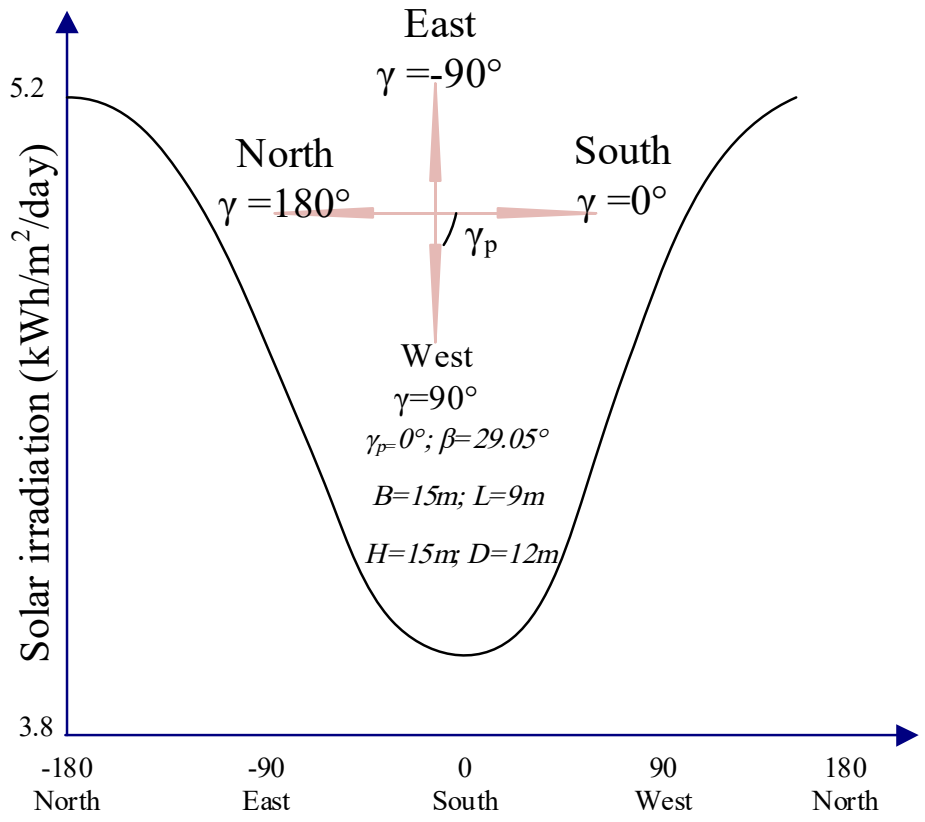

Different position of the adjacent building

Figure 10. Variation of monthly average daily irradiation with different positions of the adjacent building (width of the adjacent building, $B=15 \mathrm{~m}$, length of the adjacent building, $\mathrm{L}=9 \mathrm{~m}$, relative height of the adjacent building, $\mathrm{H}=15 \mathrm{~m}$, horizontal distance of the adjacent building from BIPV panel, $\mathrm{D}=12 \mathrm{~m}$ ) at inclination angle of BIPV panel, $\varphi=28.70^{\circ}$, when the BIPV panel is south facing, September 2017 [51].

In a rather more detailed study, Yadav et al. [44] examined the influence of shading, 'caused by different plan orientations of an adjacent building' on the optimum angle of orientation, in relation to the azimuth and the angle of inclination of the BIPV module. The test was conducted on 15 May 2018, for an optimally tilted semi-transparent BIPV twostoried single room system with consideration of periodic nature of insolation parameters 
evaluated for the warmest day of the year. The BIPV system is integrated as the south facing roof top of a two-storied sample building in Delhi, India. The optimum inclination angle was exactly the same as the latitude of the location in Delhi, India, when there were no shadow effects. The optimum inclination angle decreased, with an increase in shading and increased as the 'shadow effect', caused by sky-blocking, decreased. Furthermore, if the adjacent building was situated in a south-facing position, there was a much greater impact on level of irradiation on the panel than in any other orientation.

Therefore, the effects of shading also have an impact on the energy performance, significantly affecting the irradiation capture of the BIPV system. Capture-losses are also similarly observed with soiling.

\subsubsection{Effect of Soiling on Irradiation Capture}

Soiling of the BIPV panel with dust or accretion with snow or ice may cause the BIPV module to become temporarily shaded. Borrebäk et al. [10] carried out research on the 'challenges, strategies and opportunities' created by the formation of ice and snow on the external surface of semi-transparent BIPV in cold climate regions. Unlike the rather more predictable energy losses detailed above, losses associated with accumulations of ice and snow in winter are less predictable, creating major discrepancies in the 'estimated annual specific yield' and actual output values, as exemplified by a study in Norway [49]. In addition to the 'lower incident light intensity' on the module in arctic and sub-arctic regions, the occurrence of ice and snow in many different forms can impact the efficiency of the solar panel in different ways [10]. In some cases, the solar module can be completely covered rendering it completely ineffective in producing electricity due to the passage of solar radiation being blocked; in other cases, coverage can be minimal or partial, resulting in less significant losses of output. Mitigation strategies for the complex differences between ice and snow are also not a simple matter, with an 'application-based approach', employing a bespoke range of active and passive measures, being suggested by the study. Even 'application-based approaches' require evaluation to ensure that the benefits achieved from removing the snow or ice do not outweigh the energy output of the chosen solution. A great deal of further research would be needed to yield overall viable solutions and to understand how energy output could be maximised.

The effects of soiling due to the accumulation of dust and other contaminants, which 'adversely affect the optical performance', are somewhat more predictable [52]. While 'dust' may be generated by pollution in urban centres, more significant effects were noted in arid or semi-arid regions, where wind direction and precipitation (or lack of it) had an impact on dust accumulation [53]. Seasonal variations in the thickness of the dust layer affect energy performance in a linear fashion, with larger grains proving more significant, in addition to wind speeds and the level of humidity in the atmosphere [54,55]. Losses of efficiency, resulting from impaired irradiation capture, of around $20 \%$ were reported in Kuwait, California, Saudi Arabia and Mexico, at certain times of the year [56-59].

In [52], the authors investigated the energy yield losses caused by dust deposition on photovoltaic modules and the results of experimental research conducted in Poland. The locations in the order of increasing latitude, as shown in Figure 11 are Hong Kong, China; Abu Dhabi, UAE; Riyadh, Saudi Arabia; Dhahran, Saudi Arabia; Gran Canaria, Spain; Arava Valley, Israel (blue bars) and Gdansk, Poland, (green bar).

Rather surprisingly, highly polluted urban environments like Gdansk in Northern Poland (Latitude $52^{\circ}$ ) could yield losses as great as arid desert regions in the Middle East (Abu Dhabi UAE, Latitude 24.7). Reference [52] concluded that even at an optimum angle, the effects of the elements were not sufficient to clean the photovoltaic modules and that frequent cleaning was important to maintain maximum system output. 


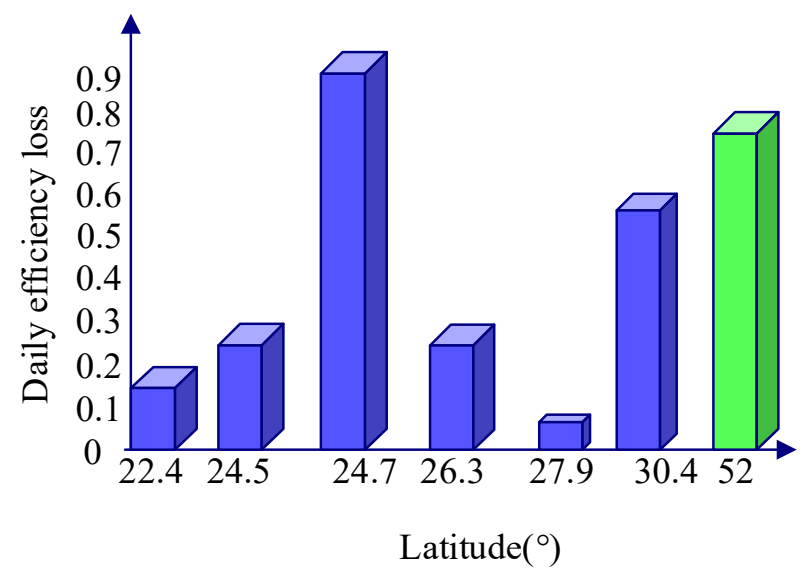

Figure 11. Maximum daily efficiency loss for various latitudes [52].

\subsubsection{Effect Is Retrofitting}

Retrofitting BIPV into existing buildings is of significant interest in countries where there are limitations placed on construction of new buildings in highly developed urban centres, which already have many high-rise structures. Hong Kong provides a good example of this, although roof mounted BIPV modules were estimated to produce almost $87 \%$ more energy than BIPV façades, due in part to the impact of shading in a densely populated city $[60,61]$. Electricity production has also been estimated for a range of member states of the International Energy Agency as shown in Table 1. While figures look very promising in some locations, it is not clear to what degree various environmental factors have been taken into account in these calculations.

\subsection{Climatic Effect on Thermal and Optical Efficiency}

Further studies compared the energy performance of semi-transparent BIPV in different climatic zones. The first analysed the energy savings delivered by a range of semitransparent BIPV façades (up to 10\% VLT) in the tropical climate of Singapore. Figure 12 shows the results of an experiment where six commercially available semi-transparent BIPV windows, four single-glazed and two double-glazed, are studied in Singapore. Moreover, selected results of semi-transparent BIPVs were also compared against commonly used window types such as single-glazing, doubled-glazing and low-emissivity windows. Modules 1 to 6 have different transparency, U-value, efficiency and technology. Modules 1,5 and 6 are amorphous silicon while modules 2, 3 and 4 are micromorph silicon. In general, energy savings were greater with higher WWR-values, ranging from $<5 \%$ to approximately $33 \%$.

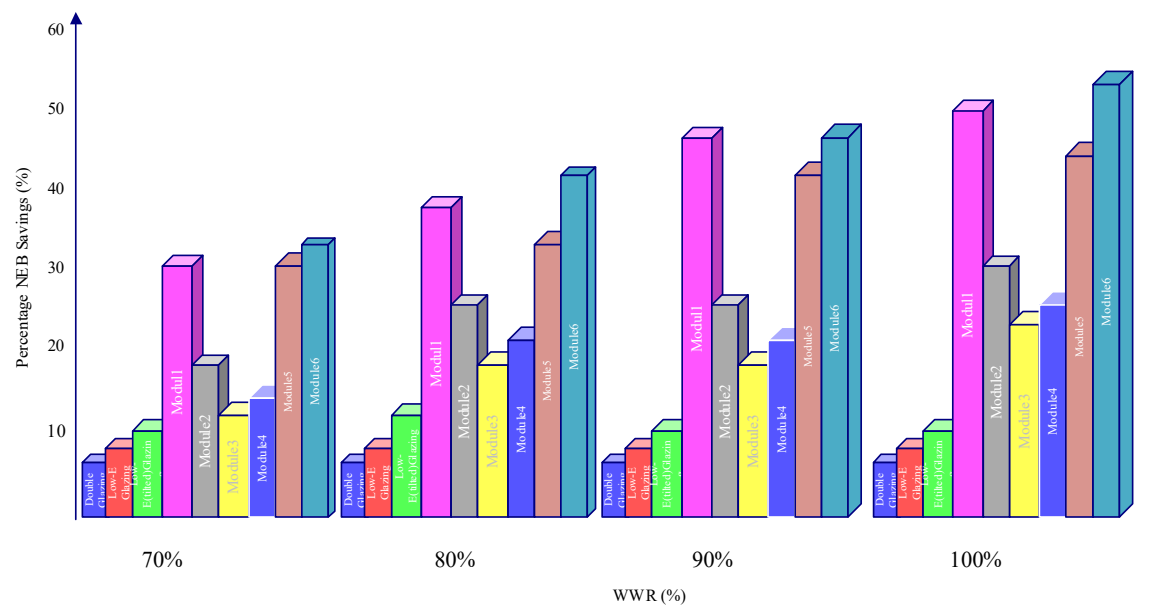

Figure 12. Percentage of total NEB (Net Energy Benefit) savings for different window types [62]. 
Table 1. The potential electricity generation capacity of BIPV for selected countries of the International Energy Agency [63].

\begin{tabular}{|c|c|c|c|c|c|c|c|}
\hline Country & $\begin{array}{c}\text { Expected } \\
\text { Roof Area } \\
\left(\mathbf{k m}^{2}\right)\end{array}$ & $\begin{array}{c}\text { Expected } \\
\text { Facades } \\
\text { Area }\left(\mathbf{k m}^{2}\right)\end{array}$ & $\begin{array}{c}\text { Expected } \\
\text { Roof } \\
\text { Energy } \\
\text { (TWh/year) }\end{array}$ & $\begin{array}{l}\text { Expected } \\
\text { Facades } \\
\text { Energy } \\
\text { (TWh/year) }\end{array}$ & $\begin{array}{c}\text { Total } \\
\text { Expected } \\
\text { Energy } \\
\text { (TWh/year) }\end{array}$ & $\begin{array}{c}\text { Actual } \\
\text { Consumption } \\
\text { (TWh/year) }\end{array}$ & $\begin{array}{l}\text { Expected } \\
\text { Demand } \\
\text { Ratio (\%) }\end{array}$ \\
\hline United States & $10,096.26$ & 3876.10 & 1662.3 & 418.3 & 2080.6 & 3602.6 & 57.8 \\
\hline United Kingdom & 914.67 & 343.00 & 83.2 & 22.1 & 105.4 & 343.5 & 30.7 \\
\hline Canada & 963.54 & 361.33 & 118.7 & 33.05 & 151.7 & 495.3 & 30.6 \\
\hline Denmark & 87.98 & 32.99 & 7.7 & 2.1 & 10.8 & 34.4 & 31.6 \\
\hline Finland & 127.31 & 32.99 & 11.7 & 3.1 & 14.8 & 76.5 & 19.4 \\
\hline Germany & 1295.92 & 485.97 & 128.3 & 31.7 & 160.0 & 531.6 & 30.1 \\
\hline Italy & 763.53 & 362.39 & 103.1 & 23.8 & 126.9 & 282.01 & 45.0 \\
\hline Japan & 966.38 & 97.26 & 117.4 & 29.4 & 146.8 & 1012.9 & 14.5 \\
\hline Netherlands & 259.36 & 168.31 & 25.6 & 6.2 & 31.8 & 99.06 & 32.2 \\
\hline Spain & 448.82 & 81.04 & 70.7 & 15.7 & 86.4 & 180.17 & 48.0 \\
\hline
\end{tabular}

The study demonstrated that in climatic conditions, with elevated outdoor temperatures, the best energy savings were, in general, delivered by a-Si double-glazed BIPV modules, which had the lowest thermal transmittance (U-values) and SHGC (g-values). Higher levels of VLT were also evident in the best-performing modules, particularly Module 1, which was not double-glazed. These findings emphasise the importance of understanding the interaction between power, thermal and optical energy performance, under specific climatic conditions [62].

\section{Emerging Technology}

It is clear that there are limitations to the existing BIPV systems, which compromise overall energy efficiency. Researchers are currently seeking to develop technologies, which maintain high levels of power conversion at elevated temperatures and offer greater efficiency in the irradiation capture process. New concept devices include Organic-Based PV, Solar Concentrator Systems, Quantum Dot Cells and Dye Sensitised Solar Cells (DSSC) although these are merely indicative of a very broad, highly complex field of research [11].

Organic-Based Photovoltaic (OPV) are solar cells, which generate electricity from sunlight, using organic semiconductors [64]. The introduction of the bulk heterojunction (BHJ) cells, which comprise an optically active layer which is 'composed of an interpenetrating network of electron donor and acceptor-materials', increased the PCE to 7.4\% [64,65]. Recent advances claim PCEs of $16.4 \%$, for non-transparent cells; however, despite the advantage of being cheap to manufacture, light weight and flexible, these cells currently yield a PCE of no more than $10.8 \%$, for semi-transparent OPV cells, with a visible transparency of around $50 \%$. This technology offers potential for further advances [66].

Regardless of the advances which have been made in this field, OPV still have one significant limitation: their photostability is adversely affected by high temperatures, meaning that they might be overall less useful in hotter climatic zones.

Solar convertor technology has been applied to OPV to 'improve the operational stability', by introducing a luminescent solar concentrator (LSC), capable of converting damaging short-wavelength photons, which release a lot of heat during the photoelectric conversion, into long wave-length photons. In addition to being more stable, the OPVLSC cells offer possibilities for 'harvesting both direct and diffuse light', optimising them for use in a wide-range of locations [66]. Indeed, solar convertor technology represents a very promising, albeit emerging technology, for semi-transparent BIPV applications, being less sensitive to the angle of system orientation and losses in efficiency associated with shadowing-effects than first- and second-generation technologies. Furthermore, triple-glazed units containing the LSC deliver a high-level of thermal-energy performance, by reducing the heating effects of solar radiation, while still facilitating the passage of 'natural light for internal illumination'. Recent technological breakthroughs have resulted in improved 'solar-collection and concentration processes', although further work is needed 
to facilitate improvements in the optical-electrical conversion process [67]. The literature interest distribution over different technologies for the recent year as shown in Figure 13.

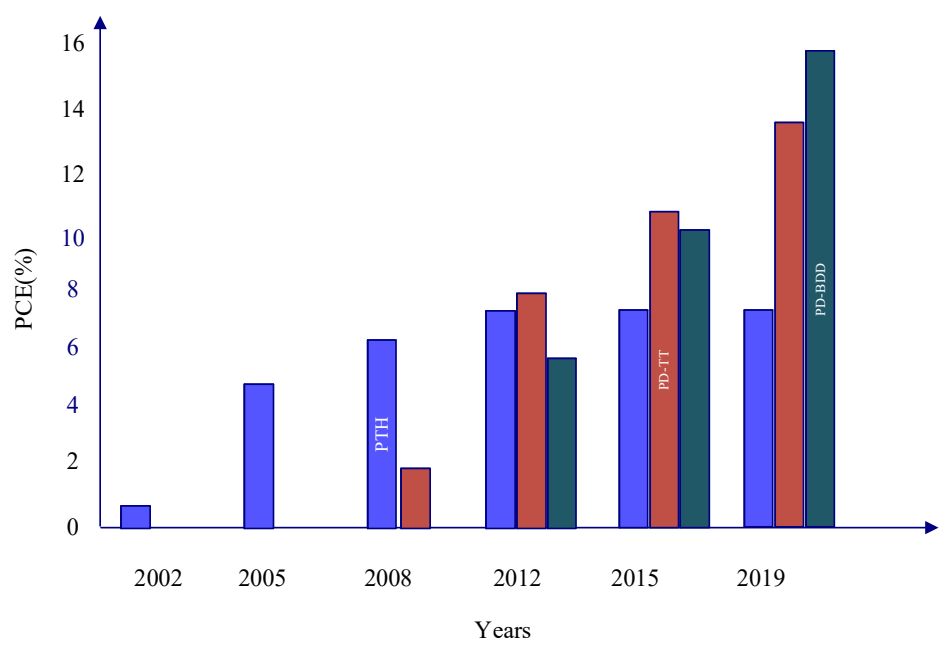

Figure 13. Research progress with regard to the efficiency enhancement for different kinds of OPV systems (Polythiophene (PTh), Poly electron-donating unit-thieno-thiophene (PD-TT) and Benzodithiophene-dione (PD-BDD)) from 2001-2019 [65].

Quantum Dot Solar Cells (QDSC) employ nanotechnology, where the structure is shown in Figure 14, increasing the output of electrons by three times, over first- or secondgeneration materials. Whereas one electron would normally be expected to be produced from one photon of light entering the cell, three are produced in the quantum dot solar cell, reducing the amount of energy wasted through heat $[68,69]$.

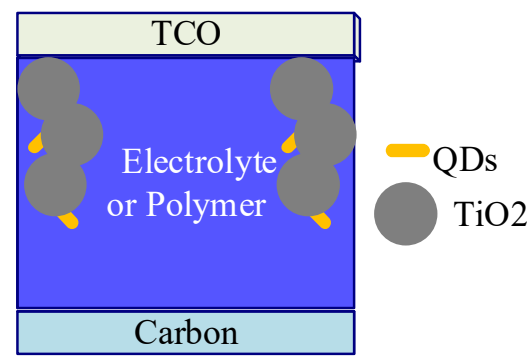

Figure 14. The structure of quantum dot sensitized solar cells, ultrathin film of colloidal QDs is sandwiched between two contacts for the extraction of photogenerated electrons and holes [69].

It is estimated that QDSC have the potential to convert around 65\% of the sun's energy into electricity, using radiation in the infrared spectrum in addition to the visible spectrum, assuming that production can be scaled up to a commercial level [69]. Some very cutting-edge research has involved combining the use of this technology with the high-efficiency semi-conductor perovskite, which has demonstrated very high PCE-levels in other applications [70].

No examination of new concept designs in solar technology would be complete, however, without taking a much closer look at Perovskite, one of the most recent success stories in this field. In December 2020, researchers at Oxford PV celebrated a new record with a perovskite solar cell, which was shown to 'convert $29.5 \%$ of solar energy into electricity [71]. Perovskite-sensitised solar cells 'emerged from the field of dye-sensitised solar cells (DSSCs)'. Their anticipated future development is discussed in [72] like solidstate DSSCs (ssDSSCs), Extremely thin absorbers (ETAs) cells, Meso-superstructured Solar Cell (MSSC) and others perovskite-based cells. 
The potential energy savings offered by using Perovskite-based technology was clearly illustrated in a study carried out by Yang et al. [47]. The following graphs highlight the advantages offered by Perovskite cells over DSSC in different climatic zones in Australia.

Solar energy output of Perovskite cells, as opposed to energy consumption, was much more favourable in all locations, and increases in output, over those achieved using a-Si cells were evident in Figure 15.
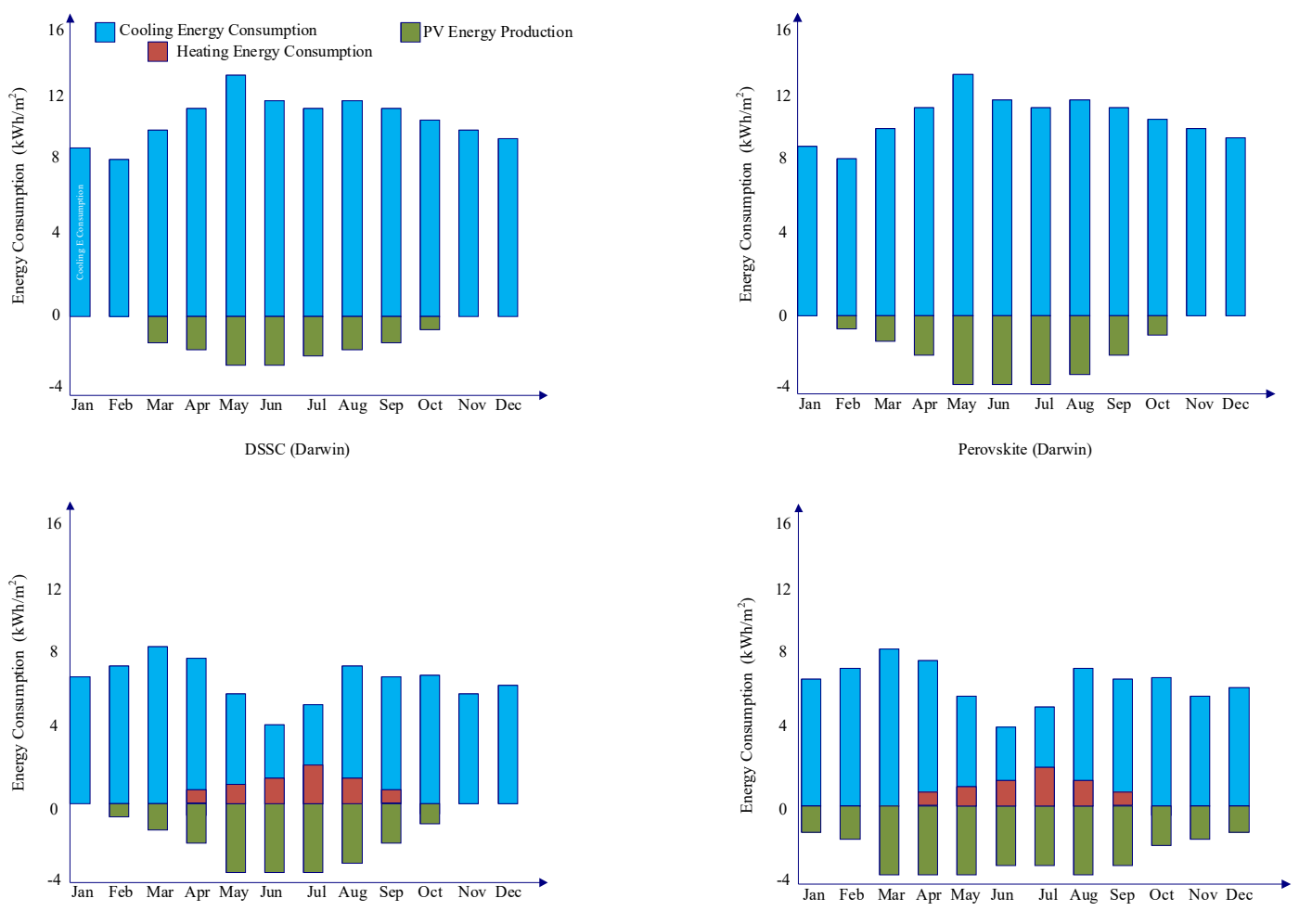

DSSC (Sydney)

Perovskite(Canberra)

Figure 15. DSSC and Perovskite solar cell for Darwin (hot, humid climate), Australia [47]. Each set of bars represents the monthly value of heating (orange) and cooling (blue) energy consumption and PV production (green) for the four models.

\section{Conclusions}

BIPV technology is a promising addition to the existent technologies for renewable and sustainable energy. In this paper, we have provided a wide review on all aspects that might be considered when targeting the energy performance of Semi-Transparent Building Integrated Photovoltaic across a range of different climatic and environmental conditions. Several studies in the literature addressed mainly the aesthetic and mechanical designs, and others tacked the integration aspects and the energy efficiency when it is integrated in a building. The location oriented has been laid out properly by the proposed framework in this paper, which is useful for establishing the most energy efficient configuration of a location-specific semi-transparent BIPV system, in addition to identifying avenues for further research aimed at reducing overall energy losses and increasing output. Specifically, this includes developing solar technology, which can deliver higher PCEs, maximise irradiation capture and not only reduce the adverse effect of heat on the PV cells but also recycle the heat produced in the generation of solar power for other purposes. These are important if a sustainable energy future is to be achieved.

Author Contributions: Conceptualization, W.I. and R.K.; methodology, H.A.; resources, R.K. and N.S.; writing-original draft preparation, R.K. and N.S.; writing-review and editing, W.I., R.K., H.A. and T.M.; supervision, W.I., T.M.; project administration, H.A.; All authors have read and agreed to the published version of the manuscript. 
Funding: This research received no external funding.

Institutional Review Board Statement: Not applicable.

Informed Consent Statement: Not applicable.

Data Availability Statement: Not applicable.

Conflicts of Interest: The authors declare no conflict of interest.

\section{References}

1. Gielen, D.; Boshell, F.; Saygin, D.; Bazilian, M.D.; Wagner, N.; Gorini, R. The role of renewable energy in the global energy transformation. Energy Strategy Rev. 2019, 24, 38-50. [CrossRef]

2. Transforming Our World: The 2030 Agenda for Sustainable Development. Department of Economic and Social Affairs. Available online: https:/ / sdgs.un.org/2030agenda (accessed on 28 April 2021).

3. Owusu, P.A.; Asumadu-Sarkodie, S. A review of renewable energy sources, sustainability issues and climate change mitigation. Cogent Eng. 2016, 3, 1167990. [CrossRef]

4. Lucchi, E.; Lopez, C.S.P.; Franco, G. A conceptual framework on the integration of solar energy systems in heritage sites and buildings. IOP Conf. Ser. Mater. Sci. Eng. 2020, 949, 012113. [CrossRef]

5. Snow, M. Designing with Solar Power: A Source Book for Building Integrated; Routledge: London, UK, 2014.

6. Zhang, T.; Wang, M.; Yang, H. A Review of the Energy Performance and Life-Cycle Assessment of Building-Integrated Photovoltaic (BIPV) Systems. Energies 2018, 11, 3157. [CrossRef]

7. Husain, A.A.; Hasan, W.Z.W.; Shafie, S.; Hamidon, M.N.; Pandey, S.S. A review of transparent solar photovoltaic technologies. Renew. Sustain. Energy Rev. 2018, 94, 779-791. [CrossRef]

8. Strong, S.J. The Dawning of Solar Electric Architecture: Feature: Photovoltaics in Buildings. Sunworld 1996, $20,3-5$.

9. Biyik, E.; Araz, M.; Hepbasli, A.; Shahrestani, M.; Yao, R.; Shao, L.; Essah, E.; Oliveira, A.C.; del Caño, T.; Rico, E.; et al. A key review of building integrated photovoltaic (BIPV) systems. Eng. Sci. Technol. Int. J. 2017, 20, 833-858. [CrossRef]

10. Borrebæk, P.-O.A.; Jelle, B.P.; Zhang, Z. Avoiding snow and ice accretion on building integrated photovoltaics-Challenges, strategies, and opportunities. Sol. Energy Mater. Sol. Cells 2020, 206, 110306. [CrossRef]

11. Jelle, B.P.; Hynd, A.; Gustavsen, A.; Arasteh, D.; Goudey, H.; Hart, R. Fenestration of today and tomorrow: A state-of-the-art review and future research opportunities. Sol. Energy Mater. Sol. Cells 2012, 96, 1-28. [CrossRef]

12. Liu, B.; Duan, S. Energy efficiency evaluation of building integrated photovoltaic systems with different power configurations. Simul. Model. Pract. Theory 2012, 29, 93-108. [CrossRef]

13. Gürtürk, M.; Benli, H.; Ertürk, N.K. Effects of different parameters on energy-Exergy and power conversion efficiency of PV modules. Renew. Sustain. Energy Rev. 2018, 92, 426-439. [CrossRef]

14. Hacker, V. Fuel Cells and Hydrogen: From Fundamentals to Applied Research; Elsevier: Amsterdam, The Netherlands, 2018.

15. Photovoltaic Research: NREL. Available online: https://www.nrel.gov/pv/ (accessed on 17 April 2018).

16. Zeman, M. Thin-Film Silicon PV Technology. J. Electr. Eng. 2010, 61, 271-276. [CrossRef]

17. Breivik, C. Building Integrated Photovoltaics-A State-of-the-Art Review, Future Research Opportunities and Large-Scale Experimental Wind-Driven Rain Exposure Investigations. Available online: https://ntnuopen.ntnu.no/ntnu-xmlui/handle/11250/23 2230 (accessed on 28 April 2021).

18. Pelle, M.; Lucchi, E.; Maturi, L.; Astigarraga, A.; Causone, F. Coloured BIPV Technologies: Methodological and Experimental Assessment for Architecturally Sensitive Areas. Energies 2020, 13, 4506. [CrossRef]

19. Maturi, L.; Belluardo, G.; Moser, D.; Del Buono, M. BiPV System Performance and Efficiency Drops: Overview on PV Module Temperature Conditions of Different Module Types. Energy Procedia 2014, 48, 1311-1319. [CrossRef]

20. Huang, P.; Lovati, M.; Zhang, X.; Bales, C.; Hallbeck, S.; Becker, A.; Bergqvist, H.; Hedberg, J.; Maturi, L. Transforming a residential building cluster into electricity prosumers in Sweden: Optimal design of a coupled PV-heat pump-thermal storage-electric vehicle system. Appl. Energy 2019, 255, 113864. [CrossRef]

21. Guo, W.; Li, D.; Cai, F.; Zhao, C.; Xiao, L. Z-Source-Converter-Based Power Conditioning System for Superconducting Magnetic Energy Storage System. IEEE Trans. Power Electron. 2018, 34, 7863-7877. [CrossRef]

22. Lee, H.-M.; Kim, S.-C.; Lee, C.-S.; Yoon, J.-H. Power Performance Loss Factor Analysis of the a-Si BIPV Window System Based on the Measured Data of the BIPV Test Facility. Appl. Sci. 2018, 8, 1645. [CrossRef]

23. Nfaoui, M.; El-Hami, K. Extracting the maximum energy from solar panels. Energy Rep. 2018, 4, 536-545. [CrossRef]

24. Li, Z.; Sumathy, K. Experimental studies on a solar powered air conditioning system with partitioned hot water storage tank. Sol. Energy 2001, 71, 285-297. [CrossRef]

25. Alrashidi, H.; Ghosh, A.; Issa, W.; Sellami, N.; Mallick, T.; Sundaram, S. Thermal performance of semitransparent CdTe BIPV window at temperate climate. Sol. Energy 2020, 195, 536-543. [CrossRef]

26. Lee, T.D.; Ebong, A.U. A review of thin film solar cell technologies and challenges. Renew. Sustain. Energy Rev. 2017, 70, 1286-1297. [CrossRef]

27. Cornaro, C.; Renzi, L.; Pierro, M.; Di Carlo, A.; Guglielmotti, A. Thermal and Electrical Characterization of a Semi-Transparent Dye-Sensitized Photovoltaic Module under Real Operating Conditions. Energies 2018, 11, 155. [CrossRef] 
28. Martín-Chivelet, N.; Guillén, C.; Trigo, J.F.; Herrero, J.; Pérez, J.J.; Chenlo, F. Comparative Performance of Semi-Transparent PV Modules and Electrochromic Windows for Improving Energy Efficiency in Buildings. Energies 2018, 11, 1526. [CrossRef]

29. Sánchez-Palencia, P.; Martín-Chivelet, N.; Chenlo, F. Modeling temperature and thermal transmittance of building integrated photovoltaic modules. Sol. Energy 2019, 184, 153-161. [CrossRef]

30. Baenas, T.; Machado, M. On the analytical calculation of the solar heat gain coefficient of a BIPV module. Energy Build. 2017, 151, 146-156. [CrossRef]

31. Chae, Y.; Kim, J.; Park, H. Building Energy Performance Evaluation of Building Integrated Photovoltaic (BIPV) Window with SemiTransparent Solar Cells; Elsevier: Amsterdam, The Netherlands, 2014.

32. Ghosh, A.; Sarmah, N.; Sundaram, S.; Mallick, T.K. Numerical studies of thermal comfort for semi-transparent building integrated photovoltaic (BIPV)-vacuum glazing system. Sol. Energy 2019, 190, 608-616. [CrossRef]

33. Marino, C.; Nucara, A.; Pietrafesa, M. Does window-to-wall ratio have a significant effect on the energy consumption of buildings? A parametric analysis in Italian climate conditions. J. Build. Eng. 2017, 13, 169-183. [CrossRef]

34. Peng, J.; Curcija, D.C.; Thanachareonkit, A.; Lee, E.S.; Goudey, H.; Selkowitz, S.E. Study on the overall energy performance of a novel c-Si based semitransparent solar photovoltaic window. Appl. Energy 2019, 242, 854-872. [CrossRef]

35. Kapsis, K.; Dermardiros, V.; Athienitis, A. Daylight Performance of Perimeter Office Façades utilizing Semi-transparent Photovoltaic Windows: A Simulation Study. Energy Procedia 2015, 78, 334-339. [CrossRef]

36. Reinhart, C.F.; Mardaljevic, J.; Rogers, Z. Dynamic Daylight Performance Metrics for Sustainable Building Design. LEUKOS 2006, 3, 7-31. [CrossRef]

37. Mohsenin, M.; Hu, J. Assessing daylight performance in atrium buildings by using Climate Based Daylight Modeling. Sol. Energy 2015, 119, 553-560. [CrossRef]

38. Do, S.L.; Shin, M.; Baltazar, J.-C.; Kim, J. Energy benefits from semi-transparent BIPV window and daylight-dimming systems for IECC code-compliance residential buildings in hot and humid climates. Sol. Energy 2017, 155, 291-303. [CrossRef]

39. Tonui, J.; Tripanagnostopoulos, Y. Improved PV/T solar collectors with heat extraction by forced or natural air circulation. Renew. Energy 2007, 32, 623-637. [CrossRef]

40. Popovici, C.G.; Hudişteanu, S.V.; Mateescu, T.D.; Cherecheş, N.-C. Efficiency Improvement of Photovoltaic Panels by Using Air Cooled Heat Sinks. Energy Procedia 2016, 85, 425-432. [CrossRef]

41. Skoplaki, E.; Palyvos, J. On the temperature dependence of photovoltaic module electrical performance: A review of efficiency/power correlations. Sol. Energy 2009, 83, 614-624. [CrossRef]

42. Cuce, E.; Bali, T.; Sekucoglu, S.A. Effects of passive cooling on performance of silicon photovoltaic cells. Int. J. Low Carbon Technol. 2011, 6, 299-308. [CrossRef]

43. Yoon, J.-H.; Shim, S.-R.; An, Y.S.; Lee, K.H. An experimental study on the annual surface temperature characteristics of amorphous silicon BIPV window. Energy Build. 2013, 62, 166-175. [CrossRef]

44. Yadav, S.; Panda, S. Thermal performance of BIPV system by considering periodic nature of insolation and optimum tilt-angle of PV panel. Renew. Energy 2020, 150, 136-146. [CrossRef]

45. Kaddoura, T.O.; Ramli, M.A.; Al-Turki, Y.A. On the estimation of the optimum tilt angle of PV panel in Saudi Arabia. Renew. Sustain. Energy Rev. 2016, 65, 626-634. [CrossRef]

46. Cheng, C.; Jimenez, C.S.S.; Lee, M.-C. Research of BIPV optimal tilted angle, use of latitude concept for south orientated plans. Renew. Energy 2009, 34, 1644-1650. [CrossRef]

47. Yang, S.; Cannavale, A.; Di Carlo, A.; Prasad, D.; Sproul, A.; Fiorito, F. Performance assessment of BIPV/T double-skin façade for various climate zones in Australia: Effects on energy consumption. Sol. Energy 2020, 199, 377-399. [CrossRef]

48. Li, Z.; Peng, W.; Yujiao, H.; Wei, T.; Yong, S. Relationships between design parameters of see-through thin film photovoltaic facade and energy performance of office building in China cold zone. Energy Procedia 2018, 152, 401-406. [CrossRef]

49. Imenes, A.G. Performance of BIPV and BAPV installations in Norway. In Proceedings of the 2016 IEEE 43rd Photovoltaic Specialists Conference (PVSC), Portland, OR, USA, 5-10 June 2016.

50. Shirazi, A.M.; Zomorodian, Z.S.; Tahsildoost, M. Techno-economic BIPV evaluation method in urban areas. Renew. Energy 2019, 143, 1235-1246. [CrossRef]

51. Yadav, S.; Panda, S.; Hachem-Vermette, C. Optimum azimuth and inclination angle of BIPV panel owing to different factors influencing the shadow of adjacent building. Renew. Energy 2020, 162, 381-396. [CrossRef]

52. Klugmann-Radziemska, E. Degradation of electrical performance of a crystalline photovoltaic module due to dust deposition in northern Poland. Renew. Energy 2015, 78, 418-426. [CrossRef]

53. Ta, W.; Xiao, H.; Qu, J.; Xiao, Z.; Yang, G.; Wang, T.; Zhang, X. Measurements of dust deposition in Gansu Province, China, 1986-2000. Geomorphology 2004, 57, 41-51. [CrossRef]

54. Jiang, F. Investigation of Solar Energy for Photovoltaic Application in Singapore. Available online: https://ieeexplore.ieee.org/ abstract/document/4510006? casa_token=jhjbVQV-5HgAAAAA:XKUZLoGHfxCxrLVettxv9phvRwSjvwTXGx41-Bmt-kUkH5 tqroVcA01Urm215cp2QzXN3g4IpP-C5 (accessed on 28 April 2021).

55. Mekhilef, S.; Saidur, R.; Kamalisarvestani, M. Effect of dust, humidity and air velocity on efficiency of photovoltaic cells. Renew. Sustain. Energy Rev. 2012, 16, 2920-2925. [CrossRef] 
56. Albusairi, H.A.; Möller, H.J. Performance evaluation of CdTe PV modules under natural outdoor conditions in Kuwait. In Proceedings of the 25th European Photovoltaic Solar Energy Conference and Exhibition/5th World Conference on Photovoltaic Energy Conversion, Valencia, Spain, 6-10 September 2010.

57. Cabanillas, R.E.; Munguía, H. Dust accumulation effect on efficiency of Si photovoltaic modules. J. Renew. Sustain. Energy 2011, 3, 043114. [CrossRef]

58. Smestad, G.P.; Germer, T.A.; Alrashidi, H.; Fernández, E.F.; Dey, S.; Brahma, H.; Sarmah, N.; Ghosh, A.; Sellami, N.; Hassan, I.A.I.; et al. Modelling photovoltaic soiling losses through optical characterization. Sci. Rep. 2020, 10, 1-13. [CrossRef]

59. Micheli, L.; Fernandez, E.F.; Smestad, G.P.; AlRashidi, H.; Sarmah, N.; Sellami, N.; Hassan, I.A.I.; Kasry, A.; Nofuentes, G.; Sood, N.; et al. A Unified Global Investigation on the Spectral Effects of Soiling Losses of PV Glass Substrates: Preliminary Results. Available online: https:/ /ieeexplore.ieee.org/abstract/document/ 8366317 (accessed on 28 April 2021).

60. International Energy Agency. Potential for Building Integrated Photovoltaics. Report IEA-PVPST7-4:2002. Available online: https: / /iea-pvps.org/?id=9\&eID=dam_frontend_push\&docID=394 (accessed on 29 April 2021).

61. Shijun, Y.; Hongxing, Y. The potential electricity generating capacity of BIPV in Hong Kong. In Proceedings of the Conference Record of the Twenty 6th IEEE Photovoltaic Specialists Conference, Anaheim, CA, USA, 29 September-3 October 1997.

62. Martín-Chivelet, N.; Gutiérrez, J.C.; Alonso-Abella, M.; Chenlo, F.; Cuenca, J. Building Retrofit with Photovoltaics: Construction and Performance of a BIPV Ventilated Façade. Energies 2018, 11, 1719. [CrossRef]

63. Ng, P.K.; Mithraratne, N.; Kua, H.W. Energy analysis of semi-transparent BIPV in Singapore buildings. Energy Build. 2013, 66, 274-281. [CrossRef]

64. Pedrasa, M.A.; Spooner, T. A survey of techniques used to control microgrid generation and storage during island operation. In Proceedings of the Australian Universities Power Engineering Conference, Melbourne, Australia, 10-13 December 2006.

65. Zheng, B.; Huo, L.; Li, Y. Benzodithiophenedione-based polymers: Recent advances in organic photovoltaics. NPG Asia Mater. 2020, 12, 1-22. [CrossRef]

66. Li, Y.; Guo, X.; Peng, Z.; Qu, B.; Yan, H.; Ade, H.; Zhang, M.; Forrest, S.R. Color-neutral, semitransparent organic photovoltaics for power window applications. Proc. Natl. Acad. Sci. USA 2020, 117, 21147-21154. [CrossRef] [PubMed]

67. Meinardi, F.; Bruni, F.; Brovelli, S. Luminescent solar concentrators for building-integrated photovoltaics. Nat. Rev. Mater. 2017, 2, 17072. [CrossRef]

68. Pan, Z.; Rao, H.; Mora-Seró, I.; Bisquert, J.; Zhong, X. Quantum dot-sensitized solar cells. Chem. Soc. Rev. 2018, 47, 7659-7702. [CrossRef]

69. Song, H.; Rao, H.; Zhong, X. Recent advances in electrolytes for quantum dot-sensitized solar cells. J. Mater. Chem. A 2018, 6, 4895-4911. [CrossRef]

70. Snaith, H.J. Perovskites: The Emergence of a New Era for Low-Cost, High-Efficiency Solar Cells. J. Phys. Chem. Lett. 2013, 4, 3623-3630. [CrossRef]

71. Zhao, Q.; Hazarika, A.; Chen, X.; Harvey, S.P.; Larson, B.W.; Teeter, G.R.; Liu, J.; Song, T.; Xiao, C.; Shaw, L.; et al. High efficiency perovskite quantum dot solar cells with charge separating heterostructure. Nat. Commun. 2019, 10, 1-8. [CrossRef] [PubMed]

72. Oxford PV Celebrates 29.5\% Conversion Rate with Perovskite Solar Cell: Solar Power Portal. Available online: https: //www.solarpowerportal.co.uk/news/oxford_pv_celebrates_29.5_conversion_rate_with_perovskite_solar_cell (accessed on 28 April 2021). 